\title{
IMPACT OF PRESIDENTIAL ELECTION ON INDONESIAN CAPITAL MARKET: AN EVENT STUDY ANALYSIS
}

\author{
Ruffino Ruven*, Achsani Noer Azam \\ School of Business, IPB University, Indonesia \\ Syarifuddin Ferry \\ Bank Indonesia, Indonesia \\ *E-mail: $\underline{\text { r.ruven@yahoo.com }}$
}

\begin{abstract}
Political events such as Indonesia presidential election in 2014, US presidential election in 2016, and Indonesia presidential election in 2019 are predicted to have effect on the performance of Indonesian capital market. It will have big impact on the dynamics of the stock market price index which become very volatile because investors will respond to that event. The purpose of this study is to analyze the differences of abnormal returns that found on Indonesia Composite Index in 5 days and 10 days event window between before and after the events. The event study methodology is used to evaluate the impact of presidential election to Indonesian capital market. This study also evaluated the significance effect of every events using paired sample test. The result of this study gives an alternative option for investors to make decision at the time of a similar event in the future.
\end{abstract}

\section{KEY WORDS}

Abnormal return, event study, Indonesia Composite Index, presidential election.

Market performance in the Indonesia Stock Exchange is influenced by various types of events that occur, including economic factors, political factors, stability and security factors, and the company's performance itself (Simatupang, 2010). Events that occur are important to analyze because at that time the country's economy became unstable. The movement of stock prices becomes very volatile because every investor will respond to the event especially at the moment of presidential election in every period. The events of presidential election have been analyzed to be able to find the right time for investors to get the maximum profit from positive abnormal returns and avoid losses from negative abnormal returns. Before the occurrence of the event, it has also been analyzed using an estimation window for 100 days because at this time issues about the events that will occur have been spread, so that investors can react faster. The reaction of investors before the occurrence of an event causes the stock index to fluctuate earlier before events actually occur. As a result, the market becomes a strong form and in this market form it is not possible to find abnormal returns.

\section{LITERATURE REVIEW}

The research related to event study from the influence of an event on stock prices was examined by Hartawan et al. (2015) who analyzed the differences in average trading volume activity and abnormal returns between before and after the legislative elections on 9 April 2014. This study used an event study method using an event window for 11 days consisting of 5 days before election events, days election events, and 5 days after the legislative election events. In addition, this study uses data on daily stock trading volume, number of shares outstanding, daily closing stock prices, and Indonesia Composite Index value and uses the market adjusted model. The results showed that based on statistical tests of average trade volume and average stock abnormal returns during the event period, it was 
found that there was no difference in average trading volume and a significant average abnormal return between before and after legislative election events.

Akben Elif (2015) reviewed the effect of announcements of Turkish company mergers and acquisitions on the company's stock price for the period 2000-2014, then found 67 announcements of mergers and acquisitions during that period. The method used is event study by using the event window for 21 days. The results of this research are the finding of positive significant abnormal returns in companies that make mergers and acquisitions of 5.25 to 8.53 percent. I., Antoniadis (2014) examined the effect of mergers and acquisitions of 3 major Greek banks in July 2010 on the share price of the banking sector. The method used is the event study method with the results of finding significant abnormal returns from the 2 banks, while 1 more bank is not affected by the mergers and acquisitions made because there are no significant abnormal returns found.

Ali et al. (2011) examined the political events that occurred with the Lahore Stock Exchange (LSE) index in Pakistan by selecting 15 random political events that occurred between 2003 and 2009. The results found were only a few political events that had an influence on the temporary LSE index other political events have no influence. Bilada $A$ (2011) examines the influence of 25 extreme events consisting of political, social, and economic events on stock price sectoral indices and joint stock price indices using the event study method, market model (OLS) for expected return calculations, and t-test for see abnormal returns between before and after extreme events occur. The results obtained are that there are several events that affect the price of these stock indices, while other events have no effect.

Floros (2008) examined the effect of parliamentary election events on the Athens Stock Exchange (ASE) in Greece in the 1996-2002 using the event study method. The results showed that 3 months before the occurrence of parliamentary elections, the ASE price index increased. Meanwhile, the ASE price index declined 3 months after the events of parliamentary elections. Manurung and Cahyanti (2007) reviewed the 2004 political elections on various industrial sectors on the Jakarta Stock Exchange (JSE) using the event study method and obtained results in the form of significant negative abnormal returns in several sectors. Statistically, the average abnormal return between before and after the election did not experience a significant difference. A similar study was also conducted by Rizal (2005) who reviewed the capital market reaction to the 2004 elections by using the event study method, but using the LQ45 index with the results that there were no significant abnormal returns between before and after the 2004 election against the LQ45 index.

Asmita (2005) also examined the same thing, namely the reaction of the capital market to the 2004 elections which was assessed by abnormal returns and trading volume. The results obtained were that there were abnormal returns in the 2004 election period, but based on testing the average abnormal return and the average stock trading volume between before and after the election did not show significant results. Meidawati and Harimawan (2004) examined the effect of legislative election events in Indonesia on stock returns on the LQ45 index by using the event study method as an analytical tool. The event window used was for 10 days before and 10 days after the legislative election event and the results were that the 2004 legislative elections had an influence on the volume of stock trading, but did not significantly affect the abnormal return on the stock. So that it can be said that investors cannot obtain maximum profits in that period because of the small value of abnormal returns.

\section{METHODS OF RESEARCH}

This research was carried out by means of a quantitative approach on the Indonesia Stock Exchange using the event study method. In addition, testing of the significance of abnormal returns is done by using statistical paired sample test. This study used secondary data of Indonesia Composite Index daily price and exchange rate of Rupiah against USD. This daily data is obtained from the website www.finance.yahoo.com, www.idx.co.id, and www.go.bi.id. 
The framework was built to analyze the influence of political event especially the US presidential election in 2016 on the Indonesia Composite Index using the event study method (Figure 1). According to Bodie et al. (2014) event study is a financial research technique to study the impact of a particular event on the dynamics of abnormal returns. MacKinlay (1997) assures that daily analysis will yield better results than monthly analysis.

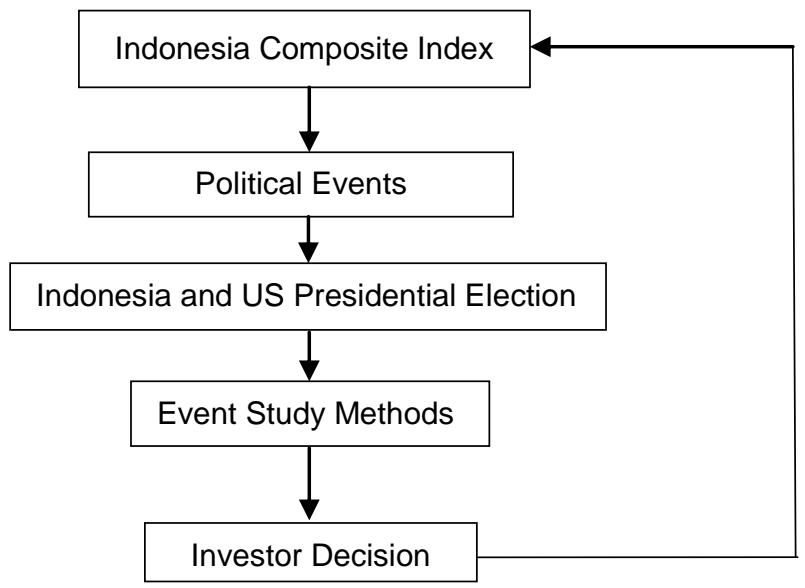

Figure 1 - Research Framework

Market dynamics are analyzed based on abnormal returns at each event. This study uses two types of event window. First, an event window for 11 days, consisting of 5 days before the event, 1 day when the event occurred, and 5 days after the event. Second, an event window for 21 days, consisting of 10 days before the event, 1 day when the event occurred, and 10 days after the event. Expected returns on Indonesia Composite Index (ICI) in this study are calculated using mean adjusted model for 100 days estimation window. In addition, a paired sample test is performed on the average abnormal return value between before and after the event. The results of this study are expected to be information and references for investors in making decisions to invest in the right time.

The calculation of abnormal return is central to this methodology. Abnormal returns are calculated, as the difference of the actual returns minus the expected returns. The actual returns of stock $i$ at $t$ time is calculated using the following relationship:

$$
R_{i t}=\frac{P_{i t}-P_{i(t-1)}}{P_{i(t-1)}}
$$

Where: $R_{i}$ is the actual returns of the stock and $P_{i}$ is the closing price of the stock price at $t$ time. After calculating the actual returns, the expected returns on Indonesia Composite Index use mean adjusted model for 100 days estimation window:

$$
E\left(R_{i}\right)=\frac{\sum_{j=1}^{T} R_{i j}}{T}
$$

Where: $E\left(R_{i}\right)$ is the expected returns of the stock, $R_{i j}$ is the actual returns of stock $i$ at $j$ time. $\mathrm{T}$ is 100 days of estimation window. The following step is to calculate abnormal returns as the difference between expected returns and actual returns of the stock $i$ at t time using equation:

$$
A R_{i t}=R_{i t}-E\left(R_{i}\right)
$$

Where: $\mathrm{AR}_{\mathrm{it}}$ is the abnormal returns of the stock. Abnormal returns show the change in the price of the stock caused by the US presidential election. Cumulative abnormal return (CAR) is also calculated to count the total ARs in the event window using equation: 


$$
C A R_{i t}=\sum_{t-5}^{t+5} A R_{i t}
$$

Where: $\mathrm{CAR}_{\mathrm{it}}$ is the cumulative abnormal return of the stock for time t. The calculation for average abnormal return (AAR) is performed using the following equation:

$$
A A R_{i t}=\frac{1}{t} \sum_{i=1}^{t} A R_{i t}
$$

Where: $A_{A R}$ it is the average abnormal return of the stock for time t. The AAR is used to test the significance between before and after the event. The first step is calculating standard deviation using the following equation:

$$
S_{i}=\sqrt{\frac{\sum_{t=1}^{n}\left(A R_{i t}-A A R\right)^{2}}{n-1}}
$$

Where: $S_{i}$ is the standard deviation and $n$ is total day in event window. The second step is calculating $T_{\text {count }}$ to compare with $T_{\text {table }}$ if the AAR between before and after the event is significant or not using the following equation.

$$
T_{\text {count }}=\frac{A A R_{\text {after }}-A_{A R_{\text {before }}}}{\sqrt{\left(\frac{s_{\text {after }}}{n_{1}}\right)+\left(\frac{S_{\text {before }}}{n_{2}}\right)}}
$$

Where: $T_{\text {count }}$ is the value that is used to compare with $T_{\text {table. }} S_{\text {after }}$ and $S_{\text {before }}$ are the standard deviation between before and after the event. $n_{1}$ and $n_{2}$ are the time periods between before

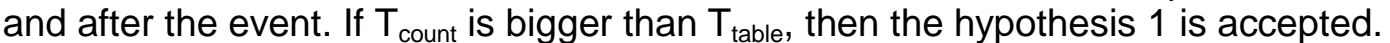

Hypothesizes of this study are:

- Hypothesis 1: There is a significant difference in average abnormal return, before and after the event;

- Hypothesis 2: There is a difference at the result of different event window on the same event.

\section{RESULTS OF STUDY}

There are seven events of Indonesia presidential election but all of them did not have significance effect to the Indonesia Composite Index (ICI). This is one of the complete analyses which are Indonesia presidential election in 2019 event and the other events is not shown in this journal. The Indonesian presidential election was held on $17^{\text {th }}$ April 2019 to determine who would be the president and vice president between the Joko Widodo-Ma'ruf Amin and Prabowo Subianto-Sandiaga Uno. During the event window, the ICI became very volatile because the 2019 Indonesian presidential election was safe and peaceful but there was intense competition between the two candidates since the previous presidential debate. Both are equally strong and have equal opportunities to become Indonesia's president for the 2019-2024 period. The quick count results after the election stated that the winner of the 2019 Indonesian presidential election was Joko Widodo, but Prabowo Subianto gave a statement that he was the winner.

This uncertainty causes economic instability so it would be better to wait for the official announcement from official organization, but until that time the Indonesian market will certainly fluctuate. At the time of the event, positive abnormal returns were found on the Indonesia Composite Index, so it could be said that the Indonesian presidential election in 2019 were positively responded by the Indonesian capital market. Abnormal return that were found in different event window was not much different, it was around 0.0003 point. Besides, rupiah rate against USD also fluctuate around the event but not much different from $\mathrm{H}-10$ before the event to $\mathrm{H}+10$ after the event (Table 1). 
Table 1 - Rupiah Exchange Rate against USD and Returns of Indonesia Composite Index at the Indonesian Presidential Election Event Window in 2019

\begin{tabular}{|c|c|c|c|c|c|}
\hline \multirow{2}{*}{ Day } & \multicolumn{2}{|c|}{$(-5,+5)$ Days } & \multicolumn{2}{|c|}{$(-10,+10)$ Days } & \multirow{2}{*}{ Rate } \\
\hline & AR ICI & CAR ICI & AR ICI & CAR ICI & \\
\hline $\mathrm{H}+10$ & - & - & -0.0098 & -0.0467 & 14282 \\
\hline $\mathrm{H}+9$ & - & - & -0.0137 & -0.0369 & 14245 \\
\hline $\mathrm{H}+8$ & - & - & 0.0034 & -0.0232 & 14215 \\
\hline $\mathrm{H}+7$ & - & - & 0.0027 & -0.0267 & 14188 \\
\hline $\mathrm{H}+6$ & - & - & 0.0033 & -0.0294 & 14188 \\
\hline $\mathrm{H}+5$ & -0.0125 & -0.0171 & -0.0128 & -0.0327 & 14154 \\
\hline $\mathrm{H}+4$ & -0.0031 & -0.0047 & -0.0034 & -0.0199 & 14112 \\
\hline $\mathrm{H}+3$ & 0.0067 & -0.0015 & 0.0064 & -0.0165 & 14080 \\
\hline $\mathrm{H}+2$ & -0.0151 & -0.0082 & -0.0153 & -0.0229 & 14056 \\
\hline $\mathrm{H}+1$ & 0.0031 & 0.0069 & 0.0028 & -0.0075 & 14016 \\
\hline Event & 0.0064 & 0.0038 & 0.0061 & -0.0103 & 14066 \\
\hline $\mathrm{H}-1$ & 0.0037 & -0.0026 & 0.0034 & -0.0164 & 14067 \\
\hline H-2 & -0.0015 & -0.0064 & -0.0018 & -0.0198 & 14153 \\
\hline H-3 & -0.0114 & -0.0048 & -0.0117 & -0.0180 & 14156 \\
\hline $\mathrm{H}-4$ & -0.0018 & 0.0065 & -0.0021 & -0.0064 & 14155 \\
\hline H-5 & 0.0083 & 0.0083 & 0.0080 & -0.0043 & 14150 \\
\hline H-6 & - & - & -0.0086 & -0.0123 & 14145 \\
\hline H-7 & - & - & -0.0043 & -0.0037 & 14158 \\
\hline H-8 & - & - & 0.0017 & 0.0006 & 14182 \\
\hline H-9 & - & - & 0.0025 & -0.0011 & 14237 \\
\hline $\mathrm{H}-10$ & - & - & -0.0036 & -0.0036 & 14231 \\
\hline
\end{tabular}

Source: Yahoo Finance and Bank Indonesia, reprocessed

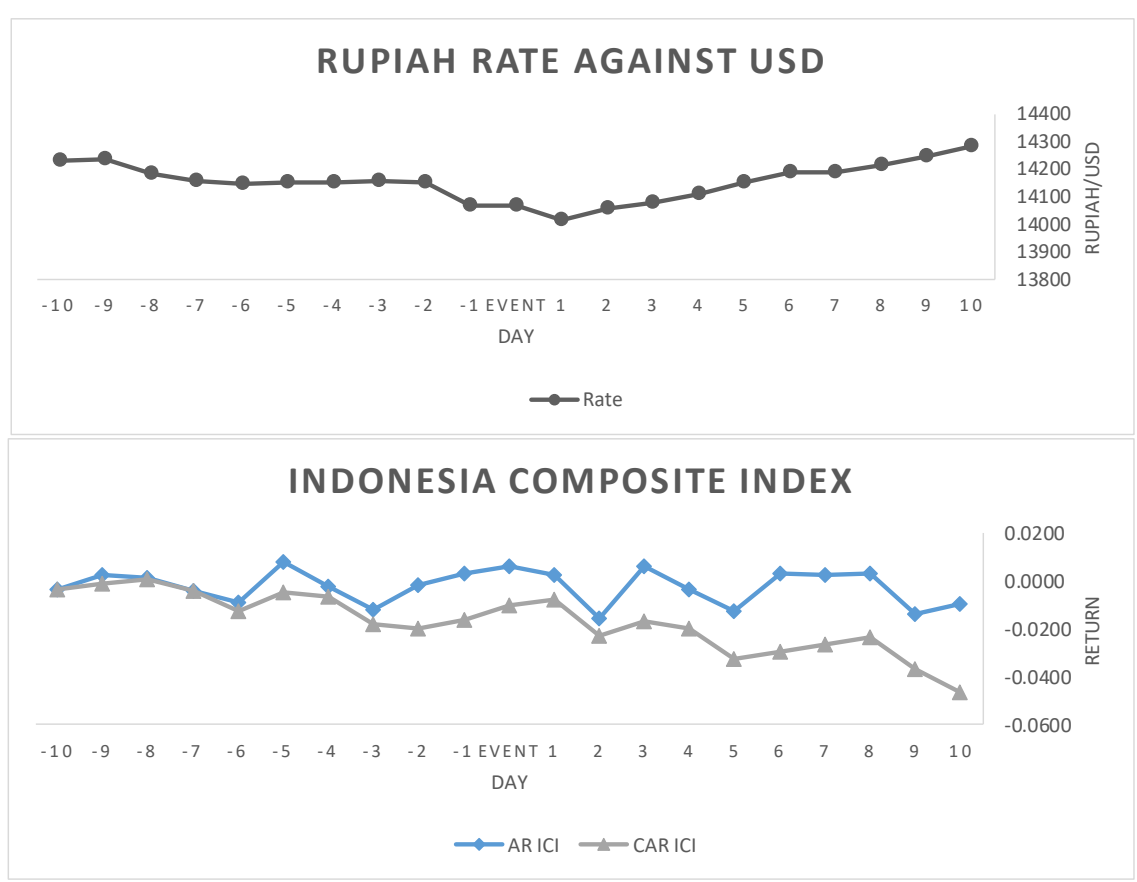

Source: Yahoo Finance and Bank Indonesia, reprocessed

Figure 2 - Movement of Rupiah Rate against USD and Return of Indonesia Composite Index at the Indonesian Presidential Election Event Window in 2019

The results of paired sample test on average abnormal return of 5 days and 10 days between before and after the event of the Indonesian presidential election in 2019 was not have a significance effect. This is evidenced by the ICl p-value of 5 days event window is 0.613 and higher than alpha at 0.05 . The $\mathrm{ICl} p$-value of 10 days event window is 0.626 and higher than alpha at 0.05 (Table 2). It can be said that the abnormal return during the event 
window is still in the normal level, so investors cannot get a significant return on this event. According to the theory of the efficient market hypothesis, in this condition the market has been in semi-strong form because abnormal returns is found but was not significant.

The seven events of Indonesian presidential election are presidential nomination day, the presidential Election Day, the announcement of the Election Day, and the inauguration day of the president. On $31^{\text {th }}$ May 2014, two candidates for Indonesia presidential election candidates were officially nominated, namely Prabowo Subianto-Hatta Rajasa and Joko Widodo-Muhammad Jusuf Kalla. The Indonesia presidential election was held on $9^{\text {th }}$ July 2014. Then, on $22^{\text {th }}$ July 2014 the winner of Indonesia presidential election was announced as Joko Widodo-Muhammad Jusuf Kalla with a percentage of $53.15 \%$ defeating Prabowo Subianto-Hatta Rajasa with a percentage of $46.85 \%$. The inauguration of President Joko Widodo and Vice-president Muhammad Jusuf Kalla was held on $20^{\text {th }}$ October 2014. On $20^{\text {th }}$ September 2018, two presidential nominations were officially nominated, namely Joko Widodo-Ma'ruf Amin and Prabowo Subianto-Sandiaga Uno. The Indonesian presidential election was held on $17^{\text {th }}$ April 2019 and the Indonesian presidential election winner was announced officially on $21^{\text {st }}$ May 2019. Impact of the Indonesian presidential election has been analyzed as seven events according to the date of the event. The result shows that all of seven events did not have significance effect on Indonesian capital market because all $T_{\text {count }}$ that have been calculated are below the $T_{\text {table }}$ at 2.776 for 5 days event window, below the $T_{\text {table }}$ at 2.262 for 10 days event window, and all of the significance value both 5 days event window and 10 days event window was above alpha at 0.05 (Table 2).

Table 2 - Significance Test Result of Indonesia Presidential Election

\begin{tabular}{cccccc}
\hline \multirow{2}{*}{ No } & \multirow{2}{*}{ Event } & \multicolumn{2}{c}{$(-5,+5)$ Days } & \multicolumn{2}{c}{$(-10,+10)$ Days } \\
\cline { 3 - 6 } & & $\mathrm{T}_{\text {count }}$ & Sig. (2-tailed) & $\mathrm{T}_{\text {count }}$ & Sig. (2-tailed) \\
\hline 1 & Indonesian presidential nomination 2014 & -0.599 & 0.581 & -0.235 & 0.819 \\
2 & Indonesian presidential election 2014 & -0.219 & 0.837 & -0.602 & 0.562 \\
3 & Indonesian presidential announcement 2014 & -1.076 & 0.342 & -1.119 & 0.292 \\
4 & Indonesian presidential inauguration 2014 & -0.693 & 0.527 & -0.244 & 0.813 \\
5 & Indonesian presidential nomination 2018 & -0.511 & 0.637 & -0.544 & 0.600 \\
6 & Indonesian presidential election 2019 & -0.548 & 0.613 & -0.505 & 0.626 \\
7 & Indonesian presidential announcement 2019 & 1.287 & 0.268 & 1.132 & 0.329 \\
\hline
\end{tabular}

Source: Yahoo Finance, reprocessed

There are four events of US presidential election and one of them has significance effect to the Indonesian capital market, but not for the others. This is the complete analysis which has significance effect of US presidential election in 2019 event on Indonesian capital market and the other events is not shown in this journal. The election of Donald Trump as the winner of the US presidential election by doing an unusual campaign and reaping a lot of criticism has a negative impact on the Asian market especially Indonesia. Trade war was begun between US and China, also global economic is going down. This event has negative significance impact on Indonesian capital market and Rupiah exchange rate against USD. Abnormal return that was found in different event window was not much different, it was around 0.0001 point. Even at the time of the event, positive abnormal return is found on Indonesia Composite Index (ICI), rupiah exchange rate has decline trend from $\mathrm{Rp} 13.022,00$ at $\mathrm{H}-10$ before the event to $\mathrm{Rp} 13.424,00$ at $\mathrm{H}+10$ after the event (Table 3).

The whole world does not expect that Donald Trump will defeat Hillary Clinton in the US presidential election in 2016. Indonesian market did not quickly enough to respond the event and causing a significant negative return in 5 days event window on Indonesia Composite Index between before and after the event. The decline trend of Indonesia Composite Index prices after the event made Rupiah exchange rate against USD also decreasing (Figure 3). 
Table 3 - Rupiah Exchange Rate against USD and Returns of Indonesia Composite Index at the US Presidential Election Event Window in 2016

\begin{tabular}{cccccc}
\hline \multirow{2}{*}{ Day } & \multicolumn{2}{c}{$(-5,+5)$ Days } & \multicolumn{2}{c}{$(-10,+10)$ Days } & \multirow{2}{*}{ Rate } \\
\cline { 2 - 5 } & AR ICI & CAR ICI & AR ICI & CAR ICI & \\
\hline H+10 & - & - & 0.0097 & -0.0659 & 13424 \\
H+9 & - & - & -0.0055 & -0.0756 & 13438 \\
H+8 & - & - & -0.0057 & -0.0701 & 13408 \\
H+7 & - & - & 0.0002 & -0.0644 & 13385 \\
H+6 & - & - & 0.0198 & -0.0646 & 13347 \\
H+5 & -0.0085 & -0.0772 & -0.0086 & -0.0843 & 13338 \\
H+4 & -0.0234 & -0.0687 & -0.0235 & -0.0758 & 13358 \\
H+3 & -0.0412 & -0.0453 & -0.0413 & -0.0523 & 13350 \\
H+2 & 0.0055 & -0.0040 & 0.0054 & -0.0109 & 13118 \\
H+1 & -0.0115 & -0.0095 & -0.0116 & -0.0163 & 13084 \\
Event & 0.0145 & 0.0020 & 0.0144 & -0.0047 & 13090 \\
H-1 & 0.0032 & -0.0125 & 0.0031 & -0.0191 & 13082 \\
H-2 & 0.0050 & -0.0157 & 0.0049 & -0.0222 & 13103 \\
H-3 & -0.0152 & -0.0208 & -0.0153 & -0.0271 & 13050 \\
H-4 & -0.0031 & -0.0055 & -0.0032 & -0.0118 & 13058 \\
H-5 & -0.0024 & -0.0024 & -0.0025 & -0.0086 & 13036 \\
H-6 & - & - & 0.0010 & -0.0061 & 13051 \\
H-7 & - & - & -0.0025 & -0.0071 & 13048 \\
H-8 & - & - & 0.0019 & -0.0046 & 13027 \\
H-9 & - & - & -0.0009 & -0.0065 & 12997 \\
H-10 & - & - & -0.0056 & -0.0056 & 13022 \\
\hline S0 & & - &
\end{tabular}

Source: Yahoo Finance and Bank Indonesia, reprocessed

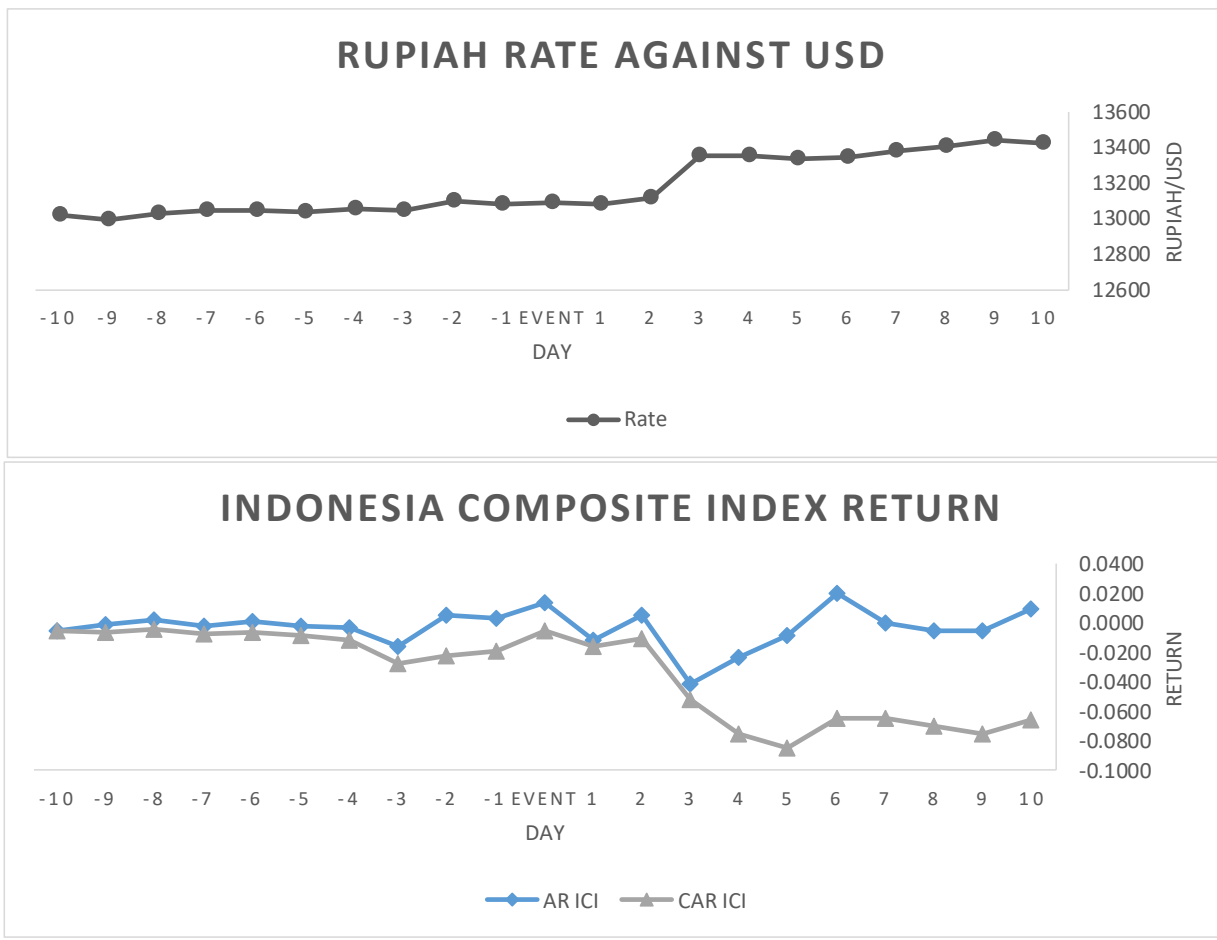

Source: Yahoo Finance and Bank Indonesia, reprocessed

Figure 3 - Movement of Rupiah Rate against USD and Returns of Indonesia Composite Index at the US Presidential Election Event Window in 2016 
The result of a different paired sample test of average abnormal return of Indonesia Composite Index between before and after the US presidential election in 2016 were had significant negative differences on 5 days event window, but had not significant negative differences on 10 days event window. This is evidenced by the ICI p-value of 5 days event window is 0.049 and lower than alpha at 0.05 . Meanwhile, $\mathrm{ICl} p$-value of 10 days event window is 0.377 and higher than alpha at 0.05 (Table 4). It can be said that the abnormal return during 5 days event window is already above normal level, so investors will get a significant return on this event. Unfortunately, this significance effect is a negative trend based on negative sign which is found on $T_{\text {count }}$, so the return on investment will be negative according to the decline trend.

The US presidential election began when Donald Trump was elected as a potential presidential candidate from the republic on $3^{\text {rd }}$ May 2016 and Hillary Clinton was selected as a potential presidential candidate from the democratic on $6^{\text {th }}$ June 2016 . After that, the US presidential election was held on $8^{\text {th }}$ November 2016 with results Donald Trump from the republic defeated Hillary Clinton from the democratic with 270 votes from all 538 votes. Then on $20^{\text {th }}$ January 2017 , Donald Trump was officially inaugurated as the 70th president of the United States. Impact of the US presidential election has been analyzed as four events according to the date of the event. The result shows that only one event of US presidential election has significance effect, other three events did not have significance effect on Indonesian capital market because all $T_{\text {count }}$ that have been calculated are below the $T_{\text {table }}$ at 2.776 for 5 days event window, below the $T_{\text {table }}$ at 2.262 for 10 days event window, and all of the significance value both 5 days event window and 10 days event window was above alpha at 0.05 (Table 4).

Table 4 - Significance Test Result of US Presidential Election

\begin{tabular}{lccccc}
\hline \multirow{2}{*}{ No } & \multirow{2}{*}{ Event } & \multicolumn{2}{c}{$(-5,+5)$ Days } & \multicolumn{2}{c}{$(-10,+10)$ Days } \\
\cline { 3 - 6 } & & Tcount & Sig. (2-tailed) & Tcount & Sig. (2-tailed) \\
\hline 1 & Donald Trump as president candidate 2016 & 0.555 & 0.609 & -0.396 & 0.701 \\
2 & Hillary Clinton as president candidate 2016 & -1.296 & 0.265 & -1.337 & 0.214 \\
$\mathbf{3}$ & US presidential election 2016 & $\mathbf{- 2 . 7 9 4}$ & $\mathbf{0 . 0 4 9 *}$ & $\mathbf{- 0 . 9 2 9}$ & $\mathbf{0 . 3 7 7}$ \\
4 & US presidential inauguration 2017 & 1.836 & 0.140 & 1.774 & 0.112 \\
\hline * = denote significance at 5\% & & & & \\
Source: Yahoo Finance, reprocessed & & & &
\end{tabular}

This condition is a moment that must be avoided by investors because they can experience significant losses from their investments in the Indonesian Composite Index near the event day. It is suggested to investors to sell their investment in Indonesia Composite Index before the event to reduce their loss. Meanwhile, the abnormal return of 10 days before and 10 days after the event is not significant, so investors cannot get a significant return, both positive or negative returns from Indonesian capital market on this event. According to the theory of the efficient market hypothesis, this condition the market is already efficient in the weak form of Indonesia Composite Index because of negative significant abnormal return is found on 5 days event window and a half-strong form on 10 days event window because of the abnormal return occurrence but not significant.

\section{CONCLUSION}

The result of the study is only one event from eleven events that has significance effect of the Indonesian capital market. This study shows the Indonesian capital market already fast enough to respond the occurrence of political events which is indicated by the existence of abnormal returns, both positive and negative returns depending on the investor's judgment of the events. If the market is fast enough, it is impossible to found abnormal return because the market already in the strong form according to efficient market 
hypothesis. This study also shows that a longer event window tends to be stable and the significance effect is only happened in a short period because of an unexpected event.

The existence of a significant negative abnormal return between before and after the events of the US presidential election in 2016 shows at this time investors will experience substantial losses. The presence of a significant abnormal return in the event window shows that the market at that time was in a weak form because the market did not react quickly to events that occurred. The winner of the US election is also unexpected event because global market hopes Hillary Clinton win the US presidential election, but the fact is out of prediction. This event makes a significant negative trend of the Indonesia Composite Index on 5 days before and 5 days after the event, but did not have significance effect on 10 days before and 10 days after the event. If the US presidential election is going to be held in 2020 , it is recommended to investors to invest in other safe stock market. Investors have to avoid to invest in Indonesia Composite Index at this moment and they have to allocate their investment to a stable stock index such as blue-chip index to avoid the risk of substantial losses.

This study has a limitation. The first limitation of this study is only using one model to calculate expected return. For further research, it is recommended to conduct analysis using different model to see whether the same event will provide the same significant level at different model. Second, the variable is used in this study is only daily stock price, so further research can add other variables such as trading volume activity.

\section{REFERENCES}

1. Akben E. 2015. Do Mergers and Acquisitions Create Value for Turkish Target Firms? An Event Study Analysis. Elsevier, Procedia Economics and Finance. 30:15-21.

2. Ali L, Daniel K, Aslam Q, Talat M, Ahmed Z. 2011. The Impact of Political Events on Lahore Stock Exchange during 2003-2009. Interdisciplinary Journal of Contemporary Research in Business. 3(1):1128-1140.

3. Asmita M. 2005. Reaksi Pasar Modal Indonesia Terhadap Pemilu 2004 (Studi Kasus Saham LQ45 di Bursa Efek Jakarta). Semarang: Universitas Diponegoro.

4. Bilada A. 2011. Dampak Extreme Events Terhadap Return Indeks Harga Saham Gabungan (IHSG) Dan Indeks Sektoral. Bogor: Institut Pertanian Bogor.

5. Bodie, Kane, 2014. Manajemen Portofolio dan Investasi 9(2). Jakarta: Salemba Empat.

6. Floros C. 2008. The Influence of the Political Elections on the Course of the Athens Stock Exchange 1996-2002. Managerial Finance. 34(7):479-488.

7. Hartawan MW, Adiputra MP, ASD Nyoman. 2015. Analisis Perubahan Volume Perdagangan Saham Dan Abnormal Return Sebelum Dan Sesudah Pemilu Legislatif 9 April 2014 (Event Study Pada Sektor-Sektor Industri Di Bursa Efek Indonesia). Jurnal Akuntansi. 3(1):15-20.

8. Antoniadis I., Alexandridis A., Sariannidis N. 2014. Mergers and Acquisitions in the Greek Banking Sector: An Event Study of a Proposal. Elsevier, Procedia Economics and Finance. 14:13-22.

9. MacKinlay AC. 1997. Event Studies in Economics and Finance. Journal of Economic Literature. 35(2):13-39.

10. Manurung AH, Cahyanti IK. 2007. Pengaruh Peristiwa Politik Terhadap Transaksi Saham Di Bursa Efek Jakarta. Jurnal Bisnis Dan Manajemen. 7(2):135-146.

11. Meidawati N, Harimawan M. 2004. Pengaruh Pemilihan Umum Legislatif Indonesia Tahun 2004 Terhadap Return Saham Dan Volume Perdagangan Saham LQ45 Di PT Bursa Efek Jakarta (BEJ). Sinergi, Kajian Bisnis Dan Manajemen. 7(1):26-36.

12. Rizal U. 2005. Reaksi Pasar Modal (BEJ) Indonesia Terhadap Peristiwa Politik Dalam Negeri (Event Study) (Pengaruh Peristiwa Pemilu Legislatif, Pilpres I, Dan Pilpres II Terhadap Perdagangan Saham LQ45 Dan Indeks LQ45). Jakarta: Universitas Indonesia.

13. Simatupang M. 2010. Pengetahuan Praktis Investasi Saham Dan Reksadana. Jakarta: Mitra Wacana Media. 